\title{
Education and the Welfare State: A Short Comment on a Complex Relationship
}

Marius R. Busemeyer, University of Konstanz

\section{A} $s$ the various contributions to this symposium impressively demonstrate, there are strong interconnections between education and other types of social policy. In the context of the ongoing structural transformation towards the service-oriented knowledge economy, education is widely believed to play a crucial role in mitigating social and economic inequality. However, as I will argue in this short essay, the linkages between education and the welfare state are much more complex than often assumed. More specifically, Busemeyer (2015) identifies three linkages between education and the welfare state regime more broadly defined: first, in terms of politics, there has been a significant overlap in the politicoeconomic coalitions promoting institutional and policy change in education as well as other social policies (Iversen and Stephens 2008; see also the contributions by Eaton and Garritzmann in this symposium). Second, the institutional design of education and training systems has implications for social inequality (see the contributions by Graf and Powell as well as Eaton); that is, as other social policies, it affects the outcomes of policy making. Third, education and welfare state institutions shape popular expectations and attitudes towards policy-making. These feedback effects contribute to stabilizing development paths of education and welfare state regimes in the long run (see also the contributions by Garritzmann and Rose in this symposium).

In the following, I am going to focus on the second aspectthe potential of education to mitigate social inequality. In a seminal contribution to the comparative welfare state literature, Wilensky (1975) expressed some doubts with regard to the effectiveness of education to reduce inequality. And indeed, the connection between education and inequality is much less straightforward than could be expected. For instance, public debates about educational reforms often center on the issue of expanding access to higher education because this is argued to be crucial in today's service-oriented knowledge economies (Wren 2013). While this may be true to a large extent, the expansion of access to higher education is not necessarily a panacea with regard to lowering inequality, because the redistributive implications of investment in higher education are complex (Ansell 2010; see also Garritzmann in this symposium). This is because investing in education creates both private as well as public benefits, the former in the form of higher wages for educated individuals, the latter by boosting the economic growth potential of the economy. When private benefits are particularly high (e.g. when additional educational investments in higher education boost the wages of the well-educated), the effectiveness of education to mitigate inequality is reduced.

Hence, in assessing the potential contribution for higher education to lowering social inequality, it is important to take into account how exactly private and public benefits are balanced out. To a large extent, this is a function of the division of labor between public and private sources of financing in higher education. In countries with a high share of private sources of education funding (the bulk of which are tuition fees), levels of socio-economic inequality are significantly higher, whereas the opposite can be observed in countries with predominantly public sources of funding (Busemeyer 2015, 194, 200). Obviously, correlation does not necessarily imply causation, but it is plausible to assume that high levels of private financing can turn into an effective access barrier to higher education for students with a low-income background. While the United States had been a pioneer with regard to opening up access to higher education in the postwar decades, the excessive growth of tuition fees in recent years accompanied by a commensurate increase in student debt has significantly diminished the potential of higher education to contribute to mitigating inequality (see the contributions by Eaton and Rose). This is different in countries in which universities are predominantly financed with public monies and where generous student subsidy regimes promote high levels of enrolment for students from low-income backgrounds, as in the Scandinavian cases (see Garritzmann).

In addition to the direct effects of financing arrangements on access to higher education, the division of labor between public and private sources of funding can also feed back on public perceptions and expectations towards the welfare state (Busemeyer 2015, chapter 5). Individuals who have incurred significant human capital investments out of their own pockets and who may be burdened with high levels of studentrelated debt are more likely to accept (or even demand) a deregulated labor market regime, which awards educational investments with significantly higher wages, contributing to higher levels of wage inequality. As is also shown in Busemeyer (2013), citizens from countries with a higher private share in education spending are less likely to support governmentinduced redistribution. Thus, a high private spending share 
lowers overall support for a generous welfare state, mitigating the potential for social policy to depress inequality.

Besides concerns related to the financing of (higher) education, a second issue of importance for the potential of education to contribute to lowering inequality is the balance between vocational education and training (VET) and academic (higher) education. As indicated above, education systems with a strong VET component are often regarded critically, because they are not well positioned to meet the needs of the service-oriented knowledge economy (Wren 2013) or because they contribute to higher levels of educational inequality by diverting youths from low-income backgrounds from pursuing higher education studies (see the contribution by Graf and Powell). Even though these claims are not unfounded, it is important to recognize that well-established VET systems can also have positive effects with regard to the labor market integration of youths with more "practical" talents. As has been argued in the literature on Varieties of Capitalism (Estévez-Abe, Iversen, and Soskice 2001), the existence of well-developed VET systems in coordinated market economies boosts the relative labor market position of youths in the lower half of the skills distribution by opening up access routes to high-quality training, ideally in a workplace setting as in apprenticeship or dual study programs. This in turn facilitates smooth transitions from education to the world of work with lower levels of youth unemployment. These are the reasons why, in many countries, apprenticeship training has become an attractive reform model again in the wake of the recent economic and financial crisis.

In sum, this short comment was meant to convey one core message: there are important linkages and complementarities between education and the welfare state regime at large, but these linkages are complex. The potential for education to contribute to lowering social inequality critically depends on two factors: the division of labor between public and private sources of education funding and the balance between academic higher education and VET. In the ongoing transformation towards the service-based knowledge economy, VET often receives less attention than it deserves. Furthermore, the continuing expansion of academic higher education needs to be accompanied by debates about its financing: public funding and subsidies are important in order to enable students from weaker social backgrounds to partake in the rise of the knowledge economy.

\section{REFERENCES}

Ansell, Ben W. 2010. From the Ballot to the Blackboard: The Redistributive Political Economy of Education. Cambridge: Cambridge University Press.

Busemeyer, Marius R. 2013. "Education Funding and Individual Preferences for Redistribution." European Sociological Review 29 (4): 707-19.

- 2015. Skills and Inequality: The Political Economy of Education and Training Reforms in Western Welfare States. Cambridge, New York: Cambridge University Press.

Estévez-Abe, Margarita, Torben Iversen, and David Soskice. 2001. "Social Protection and the Formation of Skills: A Reinterpretation of the Welfare State." In Varieties of Capitalism: The Institutional Foundations of Comparative Advantage, ed. Peter A. Hall, and David Soskice, 145-83. Oxford, New York: Oxford University Press.

Iversen, Torben and John D. Stephens. 2008. "Partisan Politics, the Welfare State, and Three Worlds of Human Capital Formation." Comparative Political Studies $41(4-5)$ : 600-37.

Wilensky, Harold L. 1975. The Welfare State and Equality: Structural and Ideological Roots of Public Expenditures. Berkeley, Los Angeles, London: University of California Press.

Wren, Anne. 2013. "Introduction: The Political Economy of Post-Industrial Societies." In The Political Economy of the Service Transition, ed. Anne Wren, 1-70. Oxford, New York: Oxford University Press. 